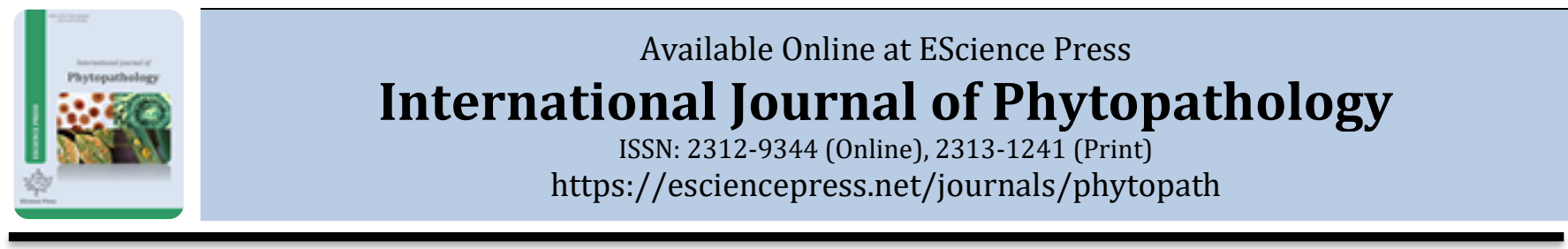

\title{
EFFECT OF NACL ON THE DEVELOPMENT OF THE OIL PALM VASCULAR WILT FUNGUS, FUSARIUM OXYSPORUM F. SP. ELAEIDIS
}

aJacques S. B. Dossa*, bMichaël Pernaci, cEuloge C. Togbé, cEuloge K. Agbossou, cBonaventure C. Ahohuendo

${ }^{a}$ Agricultural Research Center of Perennial Plants, National Agricultural Research Institute of Benin, Pobè, Benin.

${ }^{b}$ PalmElit SAS, Agropolis Park, Bat 14, 2214 Bd de La Lironde, F-34980, Montferrier sur Lez, France.

${ }^{c}$ Faculty of Agronomic Sciences, University of Abomey-Calavi BP: 526 FSA / UAC Cotonou Benin.

*Corresponding Author Email: dossajacques@yahoo.fr

\section{A B S T R A C T}

Oil palm Elaeis guineensis Jacq. (Arecaceae) is one of the cash crops that mainly contributes to the gross domestic production of growing countries. This crop is grown worldwide throughout the humid intertropical belt. Its production in Africa is mainly threatened by the telluric fungus Fusarium oxysporum f. sp. elaeidis, the causal agent of the oil palm vascular wilt. It has been reported that some environmental factors, such as soil and air salinity, may determine the survival, development and severity of phytopathogenic agents including Fusarium. The purpose of this study was to evaluate the effect of $\mathrm{NaCl}$ on growth, reproduction and pathogenic traits of this fungus by measuring mycelium daily growth, mycelium dry weight, sporulation rate, germination rate and number of infectious spores under four $\mathrm{NaCl}$ concentrations $(0 \mathrm{~g} / \mathrm{L}, 2.5 \mathrm{~g} / \mathrm{L}, 5 \mathrm{~g} / \mathrm{L}, 10 \mathrm{~g} / \mathrm{L})$ of culture medium (MM solid medium and Armstrong liquid medium). The results indicated that $\mathrm{NaCl}$ reduced radial daily growth and mycelium dry weight. In addition, the $\mathrm{NaCl}$ reduced significantly the sporulation rate and the number of infectious spores while increasing the germination rate. Overall, these results indicated the negative $\mathrm{NaCl}$ effect on the development and the fitness of this pathogenic fungus. Thus, $\mathrm{NaCl}$ inputs appeared to be a potential solution for managing Fusarium oxysporum f. sp. elaeidis in the field, if a good balance between a decrease of disease incidence and yield loss is reached.

Keywords: Fusarium oxysporum f. sp. Elaeidis, salinity, growth, sporulation, germination, disease management.

\section{INTRODUCTION}

Oil palm, Elaeis guineensis Jacq. of the Arecaceae family is grown worldwide throughout the humid intertropical belt. It represents a major source of cash income for the growing countries (Allou et al., 2017). Among all oilseed crops, oil palm brings the highest yields per hectare (Baron et al., 2017) and provides more than one-third of the world's vegetable oil production (Jacquemard, 2012). These vegetable oils are used in food and soap manufactures including cosmetics; one percent of biodiesel comes from palm oil (FAO, 2013).

However, oil palm production is subjected to fungal and bacterial attacks. Among these fungal diseases, Fusarium vascular wilt is responsible for significant damage in West and Central Africa (Flood, 2006; de Franqueville et al., 2011; Ngado et al., 2013), causing up to 70\% mortality in the field. It is the main constraint for oil palm production in Africa (Ntsomboh-Ntsefong et al., 2015). This disease is caused by a telluric fungus known as
Fusarium oxysporum f. sp. elaeidis (Foe) (de Franqueville et al., 2011; Gogbe et al., 2016). The pathogen penetrates the plant through the injured roots using aggressive enzymes, then goes through the epidermal barriers to move upwards along the intra- and intercellular pathways of the xylem to the pseudobulb. Accumulation of gum in the xylem vessels lead to a total obstruction of the vessel light and prevent the flow of the sap (Tengoua and Bakoumé, 2008). In worst cases, it results in more or less rapid desiccation of the affected palm-trees preceding the death (Asssohoun et al., 2016).

Development of phytopathogenic fungi and their incidence on hosts are highly conditioned by environmental (Renard and Ravisé, 1986; Xu et al., 2008) and climatic factors (Rossi et al., 2001; Doohan et al., 2003). Among these, mineral soil composition and particularly salinity are known to potentially have a critical impact on phytopathogenic fungi development. Indeed, soil and air salinity are one of the major 
environmental factors that may conditioned survival, development and incidence of phytopathogenic fungi (Regragui, 2005). Thus, soil salinity might be a potential way of management of fungal diseases in the field.

However, opinions are divergent with regard to the effect of $\mathrm{NaCl}$ on phytopathogenic fungi, and especially on Fusarium species. The effect of salinity varies from one species to another, either directly or indirectly. In vitro tests were performed to evaluate the effect of $\mathrm{NaCl}$ on mycelial growth, sporulation and spore germination of Verticillium albo-atrum, Phytophthora capsici, Fusarium oxysporum f. sp. radicis-lycopersici (Regragui, 2005; Sanogo, 2004; Triky-Dotan et al., 2005). Regragui (2005) showed that $\mathrm{NaCl}$ stimulates mycelial growth, sporulation and spore germination of Verticillium alboatrum while Sanogo (2004) found a positive effect on growth parameters but a negative effect on reproduction ones with Phytophthora capsici. Some studies revealed that the salinity of soil and air affects the development of Fusarium genus species (Mecteau et al., 2008; TrikyDotan et al., 2005). Furthermore, Triky-Dotan et al. (2005) observed that $\mathrm{NaCl}$ affect negatively reproduction parameters of Fusarium oxysporum f. sp. radicislycopersici; while Ragazzi and Vecchio (1992) observed that germination and germ tube length of chlamydospore of Fusarium oxysporum f. sp vasinfectum increase in substrates containing sodium chloride. Overall, these results showed that $\mathrm{NaCl}$ can affect the growth and reproductive parameters depending on the fungus species. Therefore, the pattern of the $\mathrm{NaCl}$ effect on the growth and reproductive parameters of a particular species of fungus including Foe cannot be predicted. In fact, the influence of $\mathrm{NaCl}$ on the development and reproduction of $F$. oxyporum and particularly of Foe, as well as their potential use to control the pathogen, has been poorly studied and discussed.

This study aims at evaluating the influence of $\mathrm{NaCl}$ on (i) the growth; (ii) the reproduction ability and (iii) the infectiveness of Foe to evaluate its potential use as a method to control Foe in oil palm plantations.

\section{MATERIALS AND METHODS}

Isolation of Foe: The isolate of Fusarium oxysporum f. sp. elaeidis used in this study is the isolate IB7, routinely used for screening test in the laboratory, and kept in the fridge at $4^{\circ} \mathrm{C}$ on compost soil. It was isolated in southern Benin (Guinean zone, Atlantic Department, $6^{\circ} 40^{\prime} 0^{\prime \prime} \mathrm{N}$ and $2^{\circ} 15^{\prime} 0^{\prime \prime} \mathrm{E}$ ) from a stipe of an oil palm affected with fusariosis, which was incubated on the MM culture medium. This strain was then subjected to a pathogenicity test which confirmed its virulence.

$\mathrm{NaCl}$ solutions and media preparation: MM medium was prepared using $1 \mathrm{~g}$ di-Potassium Hydrogen Phosphate (Panreac), 0.5 g Iron Sulphate (VWR Chemicals), $1.5 \mathrm{~g}$ Asparagine (Merck KGaA), $1 \mathrm{~g}$ Yeast Extract (BD), $25 \mathrm{~g}$ Agar agar (Kalys) and 1-liter distilled water. Armstrong medium was prepared using $20 \mathrm{~g}$ Glucose (VWR Chemicals), 0.4 g Magnesium Sulfate (VWR Chemicals), 1.6 g Potassium Chloride (VWR Chemicals), $1.1 \mathrm{~g}$ Potassium dihydrogen phosphate (VWR Chemicals), 5.9 g Calcium Nitrate (VWR Chemicals), 0.01 g Iron Chloride (VWR Chemicals), $0.01 \mathrm{~g}$ Manganese Sulfate (VWR Chemicals), $0.01 \mathrm{~g}$ Zinc Sulfate (VWR Chemicals) and 1-liter distilled water. Four $\mathrm{NaCl}$ (Qualikems) concentrations have been used: $0 \mathrm{~g}, 2.5 \mathrm{~g}, 5 \mathrm{~g}$ and $10 \mathrm{~g}$ per liter of culture medium, and 10 replicates were performed for each concentration.

Inoculation and incubation of Foe: To assess the radial daily growth, a MM solid medium Petri dish was prepared and inoculated at the center with a small calibrated amount of compost soil containing Foe. The Petri dish was placed in the incubator at $28^{\circ} \mathrm{C}$ for 10 days. Then, 10 Petri dishes of MM solid medium of each $\mathrm{NaCl}$ concentration were prepared and inoculated at the center with one culture fragment of size $1 \mathrm{~cm} \mathrm{X} 1 \mathrm{~cm}$. The forty Petri dishes were placed in the incubator at $28^{\circ} \mathrm{C}$ for 10 days.

To assess the sporulation rate, germination rate and the number of infectious spores, $5 \mathrm{ml}$ of distilled water were poured into each Petri dishes and the mycelium was scraped off with a microscopic slide. The mycelium suspensions were collected in test tubes and kept in the incubator at $28^{\circ} \mathrm{C}$ for three days in order to enhance spore germination. To assess the mycelium dry weight, one Petri dish of MM solid medium was prepared and inoculated at the center with a small calibrated amount of compost soil containing Foe. The Petri dish was placed in the incubator at $28^{\circ} \mathrm{C}$ for four days. Then, one culture fragment $1 \mathrm{~cm} \mathrm{X} 1 \mathrm{~cm}$ was collected and used to inoculate $100 \mathrm{ml}$ of Armstrong medium in an Erlenmeyer flask. This was then placed in a dark culture room for 4 days incubation at $29^{\circ} \mathrm{C}$ and shaken moderately three times a day. Then, 40 Roux flasks $(10$ for each $\mathrm{NaCl}$ concentration) containing each $100 \mathrm{ml}$ of Armstrong medium were inoculated with $2 \mathrm{ml}$ of the initial inoculum. Roux flasks were then placed in a dark culture room for 10 days at $29^{\circ} \mathrm{C}$ and shaken moderately three times a day. Afterwards, the culture was filtered using filter paper and 
transferred on test tubes previously weighted.

Data collection: Colony diameter ( $\mathrm{mm}$ ) in each Petri dish was measured every day during the incubation period at 9 am to assess radial daily growth of mycelium. Average radial daily growth (i.e. computed over the whole incubation period) and radial daily growth (i.e. radial growth from day $\mathrm{D}$ to $\mathrm{D}+1$ ) were considered.

The total number of spores and the number of infectious spores (i.e. germinated spores that have the ability to infect the plant) of each replicate were counted using a Malassez cell under microscope. For each replicate, five countings were used to take into account an effect of "petri dish" nested within "NaCl concentration" factor.

The mycelium dry weight was estimated after a desiccation period of one night in an oven at $105^{\circ} \mathrm{C}$ (Kranner et al., 2002). Desiccation was performed until stable weights of the samples were reached. To increase the effectiveness and statistical power, this experiment was performed two times following the same design and methodology, allowing to take into account an "experiment" effect.

Data analysis: ANOVAs were performed using univariate (mycelium daily growth) or multivariate (mycelium dry weight, sporulation rate, germination rate, number of infectious spores) hierarchical models. Corrected means, which take into account the effect of "petri dish" and "experiment" effect, were calculated using "LSmeans" $\mathrm{R}$ package while significant differences were assessed using Tukey LSD test. Correlation between various parameters and $\mathrm{NaCl}$ concentration were also studied using the Pearson correlation test for $\alpha=5 \%$. R version R-3.4.0 was used to perform all the ANOVAs, Tukey's and correlation tests.

\section{RESULTS}

Effect of $\mathrm{NaCl}$ concentration on the growth parameters of Foe: A significant $\mathrm{NaCl}$ effect was observed on the average radial daily growth $(P<0.001)$. The average radial daily growth was significantly lower with the $\mathrm{NaCl}$ concentration $10 \mathrm{~g} / \mathrm{L}$ than that of the three other concentrations. In addition, no significant differences were observed between the average radial daily growth under 0 $\mathrm{g} / \mathrm{L}, 2.5 \mathrm{~g} / \mathrm{L}$, and $5 \mathrm{~g} / \mathrm{L}$ (Table 1, Figure S1). The average radial daily growth under $2.5 \mathrm{~g} / \mathrm{L}$ was $0.48 \mathrm{~mm}(6.2 \%)$ higher than that of concentration $10 \mathrm{~g} / \mathrm{L}$.

Table 1. Effect of NaCl concentrations on growth parameters of Foe

\begin{tabular}{|c|c|c|c|c|c|}
\hline \multirow{2}{*}{ Parameters } & \multicolumn{4}{|c|}{$\mathrm{NaCl}$ Concentration (g/L) } & \multirow{2}{*}{$P$ value } \\
\hline & 0 & 2.5 & 5 & 10 & \\
\hline Average radial daily growth & $\begin{array}{c}8.17 \mathrm{a} \\
(8.05-8.29)\end{array}$ & $\begin{array}{c}8.22 \mathrm{a} \\
(8.1-8.34)\end{array}$ & $\begin{array}{c}8.01 \mathrm{a} \\
(7.89-8.13)\end{array}$ & $\begin{array}{c}7.74 \mathrm{~b} \\
(7.62-7.86)\end{array}$ & $* * *$ \\
\hline Radial daily growth D1 & $\begin{array}{c}12.7 \mathrm{a} \\
(12.42-12.98) \\
\end{array}$ & $\begin{array}{c}13 \mathrm{a} \\
(1.71-13.28) \\
\end{array}$ & $\begin{array}{c}12.5 \mathrm{a} \\
(12.22-12.78) \\
\end{array}$ & $\begin{array}{c}12.6 \mathrm{a} \\
(12.31-12.88) \\
\end{array}$ & NS \\
\hline Radial daily growth D2 & $\begin{array}{c}20.4 \mathrm{a} \\
(19.27-21.53)\end{array}$ & $\begin{array}{c}14 \mathrm{~b} \\
(12.87-15.13)\end{array}$ & $\begin{array}{c}13.8 \mathrm{~b} \\
(12.67-14.93)\end{array}$ & $\begin{array}{c}9.2 \mathrm{c} \\
(8.07-10.33)\end{array}$ & *** \\
\hline Radial daily growth D3 & $\begin{array}{c}10.4 \mathrm{a} \\
(8.88-11.92)\end{array}$ & $\begin{array}{c}14.4 \mathrm{~b} \\
(12.88-15.92)\end{array}$ & $\begin{array}{c}8.5 \mathrm{a} \\
(6.98-10.02)\end{array}$ & $\begin{array}{c}11.2 \mathrm{a} \\
(9.68-12.72)\end{array}$ & $* * *$ \\
\hline Radial daily growth $\mathrm{D} 4$ & $\begin{array}{c}7.5 \mathrm{a} \\
(5.69-9.31)\end{array}$ & $\begin{array}{c}13.2 \mathrm{~b} \\
(11.39-15)\end{array}$ & $\begin{array}{c}11.5 \mathrm{~b} \\
(9.69-13.31)\end{array}$ & $\begin{array}{c}11.8 \mathrm{~b} \\
(9.99-13.31)\end{array}$ & $* * *$ \\
\hline Radial daily growth D5 & $\begin{array}{c}9.6 \mathrm{a} \\
(8.01-11.19)\end{array}$ & $\begin{array}{c}7.7 \mathrm{a} \\
(6.11-9.29)\end{array}$ & $\begin{array}{c}10 a \\
(8.41-11.59)\end{array}$ & $\begin{array}{c}8.3 \mathrm{a} \\
(6.71-9.89)\end{array}$ & NS \\
\hline Radial daily growth D6 & $\begin{array}{c}6.8 \mathrm{ab} \\
(4.93-8.67)\end{array}$ & $\begin{array}{c}4.5 \mathrm{a} \\
(2.63-6.37)\end{array}$ & $\begin{array}{c}7.4 \mathrm{ab} \\
(5.53-9.27)\end{array}$ & $\begin{array}{c}8.5 \mathrm{~b} \\
(6.63-10.37)\end{array}$ & $*$ \\
\hline Radial daily growth D7 & $\begin{array}{c}5.6 \mathrm{a} \\
(4.18-7.02) \\
\end{array}$ & $\begin{array}{c}6.5 \mathrm{a} \\
(5.08-7.92) \\
(\end{array}$ & $\begin{array}{c}5.6 \mathrm{a} \\
(4.18-7.02) \\
\end{array}$ & $\begin{array}{c}6.3(\mathrm{a}) \\
(4.88-7.72) \\
\end{array}$ & NS \\
\hline Radial daily growth D8 & $\begin{array}{c}5.3 \mathrm{a} \\
(4.14-6.45)\end{array}$ & $\begin{array}{c}6 \mathrm{a} \\
(4.84-7.15)\end{array}$ & $\begin{array}{c}4.4 \mathrm{a} \\
(3.24-5.55)\end{array}$ & $\begin{array}{c}5.3 \mathrm{a} \\
(4.14-6.45)\end{array}$ & NS \\
\hline Radial daily growth D9 & $\begin{array}{c}3.4 \mathrm{a} \\
(2.11-4.68)\end{array}$ & $\begin{array}{c}2.9 \mathrm{a} \\
(1.61-4.18)\end{array}$ & $\begin{array}{c}6.2 \mathrm{~b} \\
(4.91-7.48)\end{array}$ & $\begin{array}{c}4.2 \mathrm{ab} \\
(2.91-5.48)\end{array}$ & $* *$ \\
\hline Radial daily growth D10 & $\begin{array}{c}0 \mathrm{a} \\
(-0.20-0.20)\end{array}$ & $\begin{array}{c}0 \mathrm{a} \\
(-0.20-0.20)\end{array}$ & $\begin{array}{c}0.2 \mathrm{a} \\
(-0.00-0.40)\end{array}$ & $\begin{array}{c}0 \mathrm{a} \\
(-0.20-0.20)\end{array}$ & NS \\
\hline Mycelium dry weight & $\begin{array}{c}0.82 \mathrm{a} \\
(0.79-0.84)\end{array}$ & $\begin{array}{c}0.72 \mathrm{~b} \\
(0.70-0.75)\end{array}$ & $\begin{array}{c}0.72 \mathrm{~b} \\
(0.70-0.75)\end{array}$ & $\begin{array}{c}0.78 \mathrm{a} \\
(0.76-0.81)\end{array}$ & $* * *$ \\
\hline
\end{tabular}


A decrease in radial daily growth over time was observed with the various concentrations of $\mathrm{NaCl}$. In addition, the highest differences occurred at the beginning of the incubation period, from D2 to D4 (Figure 1). Significant $\mathrm{NaCl}$ concentration effect was observed only on D2, D3, D4 $(P<0.001)$, D6 $(P<0.05)$ and D9 $(P<0.01)$ (Table 1 , Figure 1). At D2, the radial daily growth was significantly higher with $\mathrm{NaCl} 0 \mathrm{~g} / \mathrm{L}$ than with $2.5 \mathrm{~g} / \mathrm{Land} 5 \mathrm{~g} / \mathrm{L}$, which was in turn significantly higher than that of $10 \mathrm{~g} / \mathrm{L}$. The radial daily growth for $0 \mathrm{~g} / \mathrm{L}$ was $11.2 \mathrm{~mm}(122 \%)$ higher than for $10 \mathrm{~g} / \mathrm{L}$ (Table 1, Figure S2). At D3, the radial daily growth was significantly higher with $\mathrm{NaCl} 2.5 \mathrm{~g} / \mathrm{L}$ than with the three other concentrations, these later being not significantly different. The radial daily growth with 2.5 $\mathrm{g} / \mathrm{L}$ was $5.9 \mathrm{~mm}$ (69\%) higher than that under $5 \mathrm{~g} / \mathrm{L}$ (Table 1, Figure S2). At D4, the radial daily growth with
$\mathrm{NaCl}$ concentration of $0 \mathrm{~g} / \mathrm{L}$ was significantly lower than with the three other concentrations, these later being not significantly different. The radial daily growth with 2.5 $\mathrm{g} / \mathrm{L}$ was $5.7 \mathrm{~mm}(76 \%)$ higher than that of $0 \mathrm{~g} / \mathrm{L}$ (Table 1 , Figure S2). At D6, the radial daily growth with $10 \mathrm{~g} / \mathrm{L}$ was significantly higher than that of $0 \mathrm{~g} / \mathrm{L}, 2.5 \mathrm{~g} / \mathrm{Land} 5 \mathrm{~g} / \mathrm{L}$ while no significant difference was observed from $10 \mathrm{~g} / \mathrm{L}$ to $2.5 \mathrm{~g} / \mathrm{L}$. The radial daily growth with $10 \mathrm{~g} / \mathrm{L}$ was $4 \mathrm{~mm}$ (88\%) higher than that of $2.5 \mathrm{~g} / \mathrm{L}$ (Table 1, Figure S2). At D9, the radial daily growth with $5 \mathrm{~g} /$ Lwas significantly lower than that of $0 \mathrm{~g} / \mathrm{L}$ and $2.5 \mathrm{~g} / \mathrm{L}$, these later being not significantly different. Radial daily growth with $10 \mathrm{~g} / \mathrm{L}$ was not significantly different from that of the three other concentrations. The radial daily growth with $5 \mathrm{~g} / \mathrm{L}$ was $3.3 \mathrm{~mm}(114 \%)$ higher than that of $2.5 \mathrm{~g} / \mathrm{L}$ (Table 1 , Figure S2).

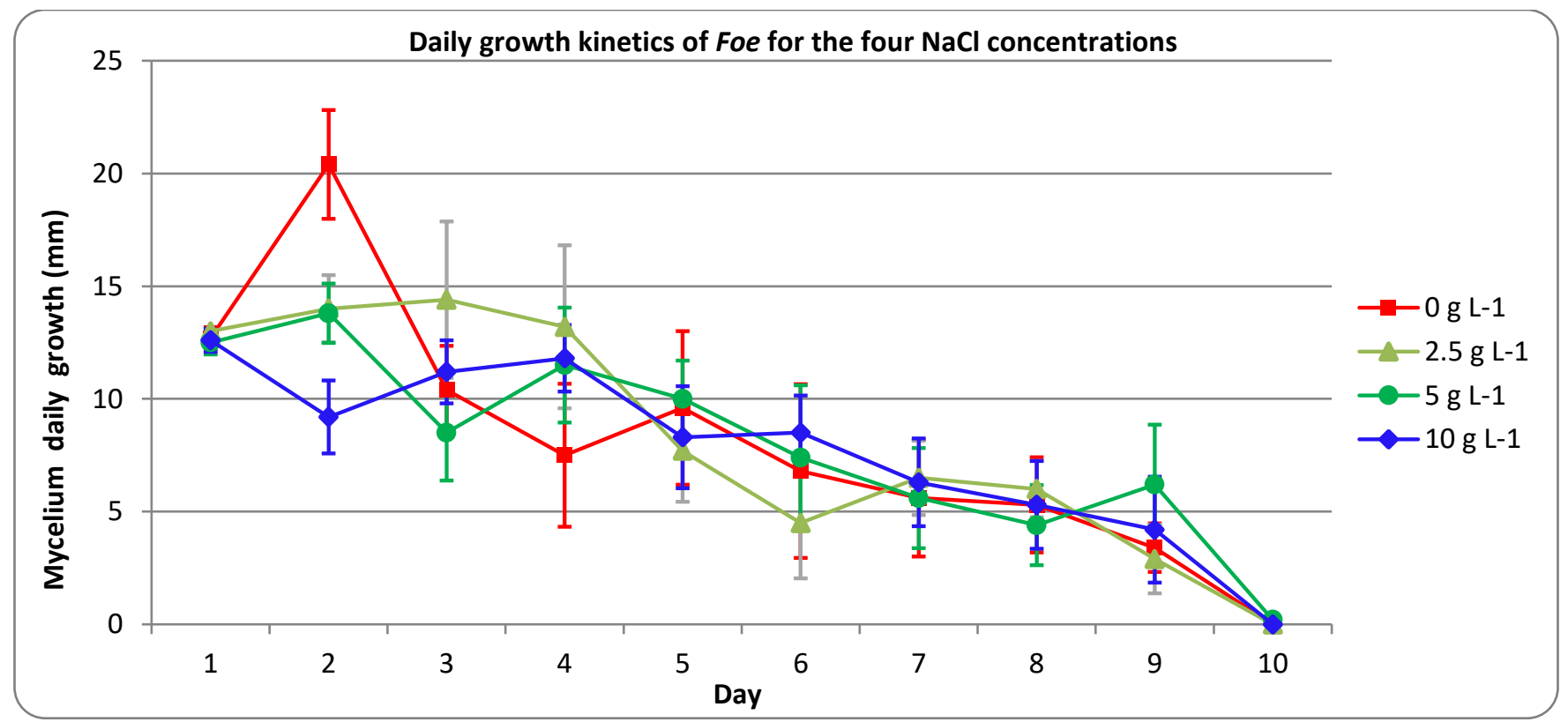

Figure 1. Radial daily growth kinetics of Foe for the four $\mathrm{NaCl}$ concentrations. Vertical bars represent the standard error.

"Experiment" effect was significant for $\alpha=5 \%(P=0.003)$. In addition, the mycelium dry weight were significantly higher with $0 \mathrm{~g} / \mathrm{L}$ and $10 \mathrm{~g} / \mathrm{L}$ than with $2.5 \mathrm{~g} / \mathrm{L}$ and $5 \mathrm{~g} / \mathrm{L}$ $(P<0.001)$ (Table 1$)$, with no significant differences within each of these two groups (Table 1, Figure S3).

Effect of $\mathrm{NaCl}$ concentration on the reproduction and infectiveness parameters of Foe: The effect of $\mathrm{NaCl}$ on the sporulation rate with the concentrations $0 \mathrm{~g} / \mathrm{L}$ and 2.5 $\mathrm{g} / \mathrm{L}$ were significantly higher than that of $5 \mathrm{~g} / \mathrm{L}$, which was in turn significantly higher than that of $10 \mathrm{~g} / \mathrm{L}$ $(P<0.001)$. The sporulation rate for concentration $0 \mathrm{~g} / \mathrm{L}$ was $220 \%$ higher than that of $10 \mathrm{~g} / \mathrm{L}$ (Table 2, Figure S4).
Germination rate under concentration $0 \mathrm{~g} / \mathrm{L}$ and $2.5 \mathrm{~g} / \mathrm{L}$ was significantly lower than that with $5 \mathrm{~g} / \mathrm{L}$ and $10 \mathrm{~g} / \mathrm{L}$ $(P<0.001)$, with no significant differences within each of these two groups. Germination rate for concentration 5 $\mathrm{g} / \mathrm{L}$ was $4.03 \%$ higher than that of concentration $2.5 \mathrm{~g} / \mathrm{L}$ (Table 2, Figure S4). With regard to the infectious spores, the number of infectious spores was significantly higher with concentration $0 \mathrm{~g} / \mathrm{L}$ and $2.5 \mathrm{~g} / \mathrm{L}$ than that of $5 \mathrm{~g} / \mathrm{L}$ and $10 \mathrm{~g} / \mathrm{L}(P<0.001)$, with no significant difference within these two groups. A number of infectious spores for concentration $0 \mathrm{~g} / \mathrm{L}$ was $112 \%$ higher than that of 10 g/L (Table 2, Figure S4). 
Table 2. Effect of $\mathrm{NaCl}$ concentration on Foe reproduction and infectiveness parameters.

\begin{tabular}{|c|c|c|c|c|c|}
\hline \multirow{2}{*}{ Parameters } & \multicolumn{4}{|c|}{$\mathrm{NaCl}$ concentration $(\mathrm{g} / \mathrm{L})$} & \multirow{2}{*}{$\begin{array}{c}P \\
\text { value }\end{array}$} \\
\hline & 0 & 2,5 & 5 & 10 & \\
\hline Sporulation rate & $\begin{array}{c}4383 a \\
(4125.57-4640.67)\end{array}$ & $\begin{array}{c}4309 \mathrm{a} \\
(4051.97-4567.07)\end{array}$ & $\begin{array}{c}1850 \mathrm{~b} \\
(1592.69-2107.79)\end{array}$ & $\begin{array}{c}1367 c \\
(1109.65-1624.75)\end{array}$ & $* * *$ \\
\hline Germination rate & $\begin{array}{c}9,73 \mathrm{a} \\
(8.74-10.72)\end{array}$ & $\begin{array}{c}9,13 \mathrm{a} \\
(8.14-10.12)\end{array}$ & $\begin{array}{c}13,16 \mathrm{~b} \\
(12.17-14.15)\end{array}$ & $\begin{array}{c}13,08 \mathrm{~b} \\
(12.09-14.07)\end{array}$ & $* * *$ \\
\hline $\begin{array}{c}\text { Number of } \\
\text { infectious spores }\end{array}$ & $\begin{array}{c}401 \mathrm{a} \\
(368.06-435.62)\end{array}$ & $\begin{array}{c}382 \mathrm{a} \\
(348.94-416.5)\end{array}$ & $\begin{array}{c}250 \mathrm{~b} \\
(217.1-284.66)\end{array}$ & $\begin{array}{c}189 \mathrm{~b} \\
(155.58-223.14)\end{array}$ & $* * *$ \\
\hline
\end{tabular}

Significance levels of $P$-values: ${ }^{*}, 5 \%{ }^{* *}, 1 \%$ and ${ }^{* * *}, 1 \%$. For each parameter, corrected means for the four concentrations are given. Corrected means with different letters are significantly different for $\alpha=5 \%$.

Correlation between $\mathrm{NaCl}$ concentration and growth, reproduction and infectiveness traits of Foe: Pearson's correlation tests revealed significant correlations between mycelium dry weight $(P<0.01)$, average radial daily growth, sporulation rate, germination rate and the number of infectious spores
$(P<0.001)$. Negative correlations were observed for average daily growth $\left(\mathrm{R}^{2}=-0.686\right)$, mycelium dry weight $\left(R^{2}=-0.418\right)$, sporulation rate $\left(R^{2}=-0.713\right)$ and the number of infectious spores $\left(\mathrm{R}^{2}=-0.547\right)$. However, positive correlation were observed for germination rate $\left(\mathrm{R}^{2}=0.361\right)$ (Figure $\left.2 \mathrm{a}-\mathrm{e}\right)$.
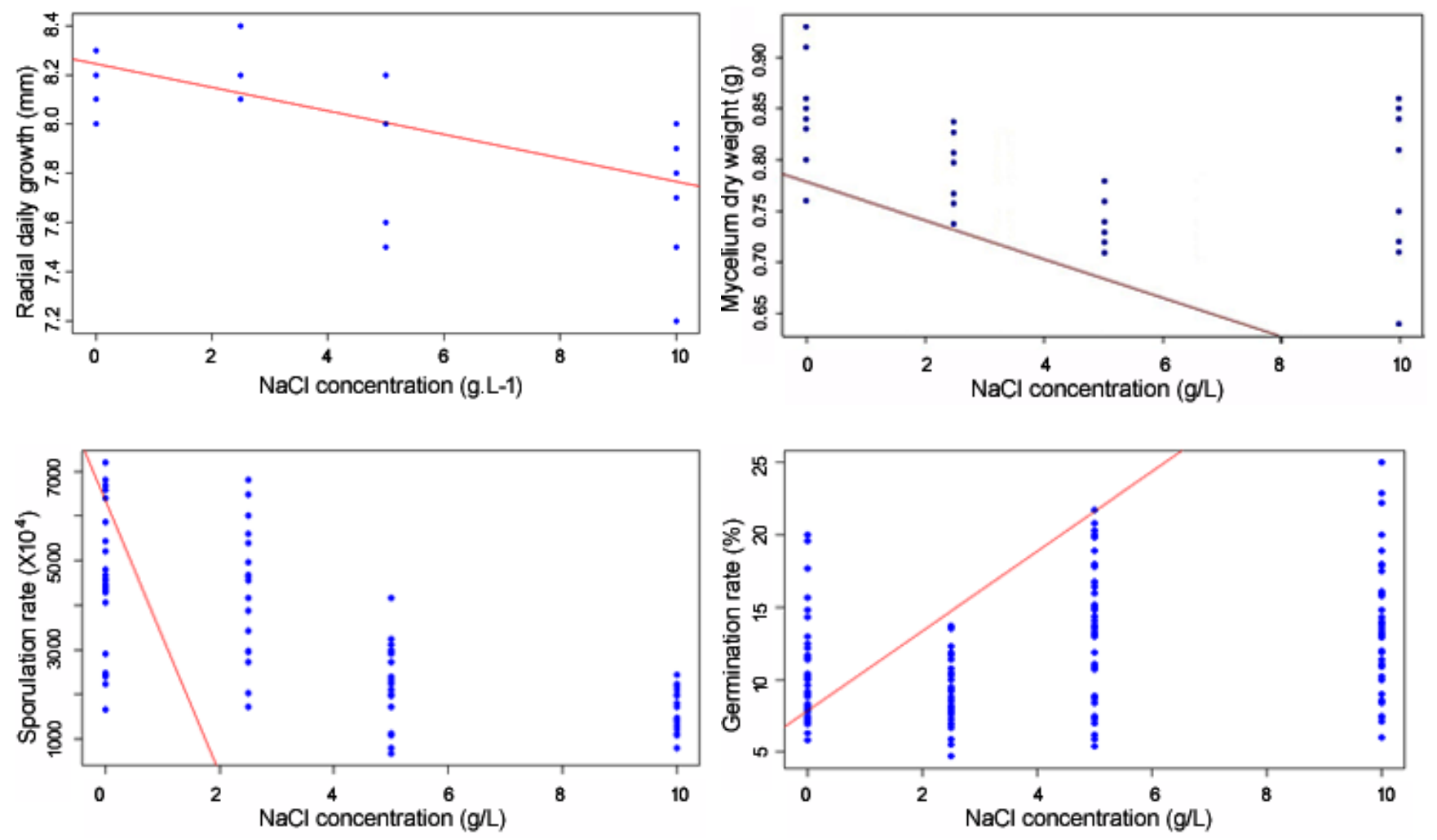

Figure 2. Correlation between $\mathrm{NaCl}$ concentrations and (a) average radial daily growth, (b) mycelium dry weight, (c) sporulation rate, (d) germination rate. $P$-values and $\mathrm{R}^{2}$ based on Pearson's correlation tests are given. Regression lines are represented by the red line.

Continued... 


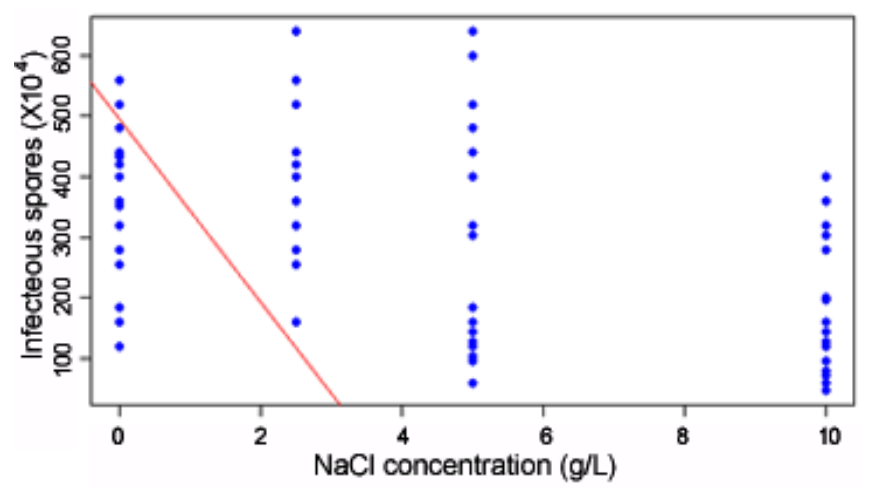

Figure 2. Correlation between $\mathrm{NaCl}$ concentrations and (e) number of infectious spores. $P$-values and $\mathrm{R}^{2}$ based on Pearson's correlation tests are given. Regression lines are represented by the red line.

\section{DISCUSSION}

This study evaluated the effects of four various concentrations of $\mathrm{NaCl} 0,2.5,5$ and $10 \mathrm{~g} / \mathrm{L}$ on the growth parameters of Foe through radial daily growth of mycelium and mycelium dry weight; the reproductive ability using sporulation rate and their infectiveness by assessing germination rate and infectious spores.

Effect of $\mathrm{NaCl}$ on growth parameters: The effect of $\mathrm{NaCl}$ on the average radial daily growth was significantly lower with $10 \mathrm{~g} / \mathrm{L} \quad(P<0.001)$ than with the three other concentrations, which were not significantly different between themselves (Table 1, Figure S1). Average radial daily growth decreased with an increase in $\mathrm{NaCl}$ concentration, which was confirmed by the significant negative correlation observed $\left(P<0.001 ; \mathrm{R}^{2}=-0.686\right)$ (Figure 2a). These results are consistent with those of Davet (1967), who found that low $\mathrm{NaCl}$ concentrations did not affect the mycelium growth of Fusarium oxysporum species. However, they are not aligned with the results of other authors. In fact, Daami-Remadi et al. (2009) observed no significant effect of $\mathrm{NaCl}$ on mycelium growth, whatever the concentration was. In addition, Besri (1981); Keren (2000); Regragui (2005); Sanogo (2004) and Boumaaza et al. (2015) observed a significant increase in mycelium growth with various $\mathrm{NaCl}$ concentration respectively on Fusarium oxysporum lycopersici, Fusarium oxysporum albendinis, Verticillium albo-atrum, Phytophthora capsici and Botrytis cinerea. It is worth noting that Boumaaza et al. (2015) observed this growth stimulation only for concentrations under $0.3 \mathrm{~g} / \mathrm{L}$. Above this threshold, a negative correlation between mycelium growth and $\mathrm{NaCl}$ concentration was observed. With regard to the $\mathrm{NaCl}$ effect on radial daily growth along the growth kinetics, more contrasting results were observed than with average radial daily growth. In fact, the significant effect of $\mathrm{NaCl}$ concentration was observed with radial daily growth, but not every day on the radial daily growth kinetics. Significant differences was noticed on D2, D3, D4 $(P<0.001)$, D6 $(P<0.01)$ and D9 $(P<0.01)$ (Table 1, Figure 1, Figure S2). Even if significant effects were observed at different days along the kinetics (from D2 to D9), we clearly observed that the highest effects were concentrated at the beginning of the radial daily growth kinetics (D2, D3 and D4). This may be explained by the fact that microorganism can use several strategies to encounter osmotic stress, such as ionic pumps. Few pumps may be produced at the beginning of the kinetics and would not allow Foe to reject $\mathrm{NaCl}$ through its membrane and wall, leading to higher $\mathrm{NaCl}$ effect during the first incubation days. Also, it was observed at D2, D3 and $\mathrm{D} 4$ that an increase in $\mathrm{NaCl}$ led to a decrease in radial daily growth (Table 1, Figure1, Figure S2). However, the radial daily growth were significantly lower with $0 \mathrm{~g} / \mathrm{L}$ than with the $2.5 \mathrm{~g} / \mathrm{L}$ at D3 and D4. Thus, even if high $\mathrm{NaCl}$ concentrations led to lower radial daily growth, it seems that the presence of of a minimum amount of $\mathrm{NaCl}$ in the medium is beneficial to the fungus. This observation was also made by Regragui (2005) with Verticillium alboatrum, and may be due to the fact that the fungus may need a minimum amount of salt to develop and ensure physiological processes. However, along with the radial daily growth kinetics, we also observed contrasting results. In fact, at D6, radial daily growth increased with increasing $\mathrm{NaCl}$ concentrations, with a significant difference between $2.5 \mathrm{~g} / \mathrm{L}$ and $10 \mathrm{~g} / \mathrm{L}$. This growth pattern was observed again at D9 with a significant increase in radial daily growth between $2.5 \mathrm{~g} / \mathrm{L}$ and $5 \mathrm{~g} / \mathrm{L}$. This contrasting $\mathrm{NaCl}$ effect along the incubation period was not described by others authors but could be considered as a real biological/physiological process. 
A significant effect of $\mathrm{NaCl}$ concentration was observed on the mycelium dry weight $(P<0.001)$ (Table 1 , Figure S3). Mycelium dry weight were significantly higher for concentrations 0 and $10 \mathrm{~g} / \mathrm{L}$ than for 2.5 and $5 \mathrm{~g} / \mathrm{L}$, with an increase of $0.1 \mathrm{~g}$ and $0.06 \mathrm{~g}$, respectively. It came out that the more the $\mathrm{NaCl}$ concentration was, the less was the mycelium dry weight. This was confirmed by a significant negative correlation $\left(P<0.01 ; \quad \mathrm{R}^{2}=-0.418\right)$ (Figure 2b). This result is contradictory with that of Sanogo (2004) who observed an increase in mycelium dry weight with an increase in $\mathrm{NaCl}$ concentration in Phytophthora capsici. However, those findings was consistent with Daami-Remadi et al. (2009) who observed a decrease in mycelium density of Verticillium dahliae with an increase in $\mathrm{NaCl}$ concentration of irrigation water. In the same way, Regragui (2005) observed no effect on mycelium dry weight for $\mathrm{NaCl}$ concentrations comprising between 0 and $10 \mathrm{~g} / \mathrm{L}$, but a regular decrease above $10 \mathrm{~g} / \mathrm{L}$.

$\mathrm{NaCl}$ effect on reproduction and infectiveness traits: Sporulation rates were significantly higher with $\mathrm{NaCl}$ concentrations 0 and $2.5 \mathrm{~g} / \mathrm{L}$ than with $5 \mathrm{~g} / \mathrm{L}$, this later being significantly higher than that of $10 \mathrm{~g} / \mathrm{L}$ (Table 2 , Figure S4). Foe sporulation decreased with increasing $\mathrm{NaCl}$ concentration and this was confirmed by the significant negative correlation observed $\left(P<0.001 ; R^{2}=-\right.$ 0.713 ) (Figure 2c). This result was contradictory to other authors' observations. In fact, Regragui (2005); DaamiRemadi et al. (2009) and Boumaaza et al. (2015) observed stimulation of sporulation rate with Verticillium alboatrum, Verticillium dahliae and Botrytis cinerea when $\mathrm{NaCl}$ concentration increased. However, our result is consistent with those of Sanogo (2004) who observed a decrease in sporangium production Phytophthora capsici with an increase in $\mathrm{NaCl}$ concentrations.

A significant $\mathrm{NaCl}$ effect was observed on the germination rate $(P<0.001)$ (Table 2$)$. In fact, germination rates were significantly lower with $\mathrm{NaCl}$ concentrations 0 and 2.5 $\mathrm{g} / \mathrm{L}$ than with 5 and $10 \mathrm{~g} / \mathrm{L}$, without significant differences within these two groups (Table 2, Figure S4). Germination rate increased with increasing $\mathrm{NaCl}$ concentrations, which was confirmed by the significant positive correlation observed $\left(P<0.001 ; \quad \mathrm{R}^{2}=0.361\right)$ (Figure 2d). This result is contradictory to those of Sanogo (2004); Boumaaza et al. (2015) and Ragazzi and Vecchio (1992) who reported respectively a negative effect of $\mathrm{NaCl}$ on germination rate of Phytophthora capsici,

Botrytis cinerea and Fusarium oxysporum f. sp vasinfectum.

The number of infectious spores was significantly higher $(P<0.001)$ with $\mathrm{NaCl}$ concentration of 0 and $2.5 \mathrm{~g} / \mathrm{L}$ than with that of 5 and $10 \mathrm{~g} / \mathrm{L}$, without significant differences within each group (Table 2, Figure S4). The number of infectious spores decrease with a decrease in $\mathrm{NaCl}$ concentration, which was confirmed by the significant negative correlation $\left(P<0.001 ; \mathrm{R}^{2}=-0.547\right)$ (Figure 2e).

Variation between growth parameters: $A$ decrease in both radial growth and mycelium dry weight was observed with the increase in $\mathrm{NaCl}$. This suggests that even if $\mathrm{NaCl}$ impacted negatively Foe growth, it would not impact mycelium density although this could be the case (Daami-Remadi et al., 2009). In fact, a decrease in radial growth without modification of mycelium dry weight would result in an increase in mycelium density (i.e. wall thickening). It was not the case with Foe since both parameters decrease with the increase in $\mathrm{NaCl}$ concentrations, suggesting a stable mycelium density. However, the stronger negative correlation between $\mathrm{NaCl}$ concentration and radial growth $(P<0.001)$ than between $\mathrm{NaCl}$ and mycelium dry weight $(P<0.01)$ might reflect that they did not strictly covariate, thus leading to an increase in mycelium density. In addition, there was no evidence that other morphological parameters (branching) were not affected by $\mathrm{NaCl}$. These aspects would need deeper investigations (microscopic observations) in order to be able to study the effect of $\mathrm{NaCl}$ on Foe morphology.

Variation between reproduction and infectiveness parameters: $\mathrm{NaCl}$ may act on reproduction and infectiveness parameters of a phytopathogenic fungus, with more or fewer constraints. Thus, $\mathrm{NaCl}$ effect on the number of infectious spores may vary depending on its effect on parameters that compose this composite trait that is sporulation rate and germination rate. Indeed, an increase of sporulation rate with the increase in $\mathrm{NaCl}$ concentration, at a constant germination rate, would lead to a higher number of infectious spores and controversely. In the case of an $\mathrm{NaCl}$ effect on one trait or the other, it may lead to a positive or negative impact in infectiveness, depending on the respective effects of $\mathrm{NaCl}$ on these two traits. In the case of Foe, we observed that $\mathrm{NaCl}$ led to a decrease in infectiveness. In fact, despite a positive $\mathrm{NaCl}$ effect on the germination rate, the decrease in sporulation rate is too high to be compensated.

Variation between growth, reproduction and infectiveness parameters: $\mathrm{NaCl}$ impacted both growth, reproduction and infectiveness parameters. $\mathrm{NaCl}$ 
impacted negatively all the studied parameters, except the germination rate. Regragui (2005) also observed that $\mathrm{NaCl}$ had an effect on both reproduction, sporulation and infectiveness parameters with Verticillium albo-atrum, but that effect was positive. Other authors observed that $\mathrm{NaCl}$ impacted these parameters in various ways. In fact, Sanogo (2004) observed with Phytophtora capsici that $\mathrm{NaCl}$ stimulated growth but impacted negatively reproduction parameters while Daami-Remadi et al. (2009) showed that $\mathrm{NaCl}$ did not affect mycelium growth in Verticillium dahliae but reduced mycelium density and stimulated sporulation.

Toward potential management of Foe in oil palm plantations using NaCl: Basically, our results showed that $\mathrm{NaCl}$ has a negative impact on growth, reproduction and infectiveness trait of Foe, and thus could be potentially used as a method of management of the disease in the field. However, two major points have to be taken into account and need further investigations.

Firstly, we have to ensure that the negative effects observed in vitro on Foe traits lead to an effective decrease of the disease incidence on the host plant, by performing in vivo trials on plantlets in the nursery. Secondly, soil salinity is known to have a negative effect on plant growth. Indeed, suppression/ reduction of growth in salty soils occurs in all plants, but their tolerance levels and rates of growth reduction vary widely among plants (Alia et al., 1995; Yoshiba et al., 1997; Hayashi and Murata, 1998; Yeo, 1998; Sánchez et al., 1998; Ramoliya et al., 2004; Flowers, 2004; SánchezBlanco et al., 2004; Parida and Das, 2005; BenllochGonzález et al., 2005; Ghadiri et al., 2006). Usually, this suppression/ reduction of growth is followed by limitation in plant productivity. This negative effect of soil salinity has been reported for oil palm by Henry and Wan (2012). They observed that fresh fruit bunch yields from fields with salty soils were significantly lower to normal areas, with $16.5 \mathrm{t} \mathrm{ha}^{-1}$ and $23.5 \mathrm{t} \mathrm{ha}^{-1}$, respectively. In the same way, the oil-to-bunch was found to be significantly affected by salinity, ranging from $16.5 \%-18 \%$ in saline areas to $22.2 \%-22.4 \%$ in non-saline areas. This implies that even if a positive effect on Foe incidence was observed in vivo trials, it might be counterbalanced by a negative effect on oil palm growth and yield in the field. Thus, such trade-off would require field experiments to assess the best concentration to maximize the positive $\mathrm{NaCl}$ effect on disease incidence while minimizing the negative effect on productivity.

\section{CONCLUSION}

In this study, we assessed the effect of $\mathrm{NaCl}$ on growth, reproduction and infectiveness traits of the oil palm wilt fungus, Fusarium oxysporum f. sp. elaeidis. Also, we showed that $\mathrm{NaCl}$ had a negative effect on growth parameters, by reducing the radial daily growth and mycelium dry weight. There was, for instance, no evidence that $\mathrm{NaCl}$ also impact mycelium density, but this hypothesis would require further investigations. In addition, we observed a negative effect of $\mathrm{NaCl}$ on reproduction and infectiveness parameters: a reduction in sporulation rate, an increase in germination rate while resulting in a reduced number of infectious spores. Thus, $\mathrm{NaCl}$ basically impacts in a negative way the development and the fitness of this pathogenic fungus. The present work gives rise to some perspectives in terms of management of Foe in the field, and open ways to future work to assess the sustainability of such control method in oil palm plantations.

\section{ACKNOWLEDGEMENTS}

The research has been founded by the Research Center of Perennial Plants of the National Agricultural Research Institute of Benin. We are thankful to Arsène Padonou and Gaston Adossou for their help during experimentations.

\section{REFERENCES}

Alia, K. V. S. K. Prasad and P. Pardha Saradhi. 1995. Effect of zinc on free radicals and proline in Brassica and Cajanus. Phytochemistry, 39: 45-47.

Allou, D., K. O. Kouakou, D. Sekou and A. S.-P. Nguetta. 2017. Evaluation de la production de cinq genotypes de palmier a huile (Elaeis Guinnensis Jacq.) replantes sur des parcelles a haute densite de fusariose. European Scientific Journal, 13: 562-69.

Asssohoun, A. L. W., F. B. D. Gogbé, S. Diabaté, J. N. Konan, E. P. Konan, M. K. Djè, H. De Franqueville and H. Tanoh. 2016. Expression de la fusariose latente chez les jeunes plantes de palmier à huile (Elaeis guineensis jacq) inoculées avec Fusarium oxysporum f. sp. elaeidis (Foe). Journal of Applied Biosciences, 102: 9716-22.

Baron, V., S. Rafflegeau, B. Dubos, A. Flori, R. Burgos and C. Louise. 2017. Exposition des plantations de palmier à huile au risque de la pourriture du cœur dans le bassin de Quevedo, Équateur. Cahiers Agricultures, 26: 55002.

Benlloch-González, M., J. M. Fournier, J. Ramos and M. Benlloch. 2005. Strategies underlying salt 
tolerance in halophytes are present in Cynara cardunculus. Plant Science, 168: 653-59.

Besri, M. 1981. Influence de la salinité du sol et des eaux d'irrigation sur la population de Fusarium oxysporum (Schl.) f. sp. lycopersici (Sacc.) Snyd. et Hans. Phytopathologia Mediterranea, 20: 101-06.

Boumaaza, B., M. Benkhelifa and M. Belkhoudja. 2015. Effects of two salts compounds on mycelial growth, sporulation, and spore germination of six isolates of Botrytis cinerea in the western north of Algeria. International Journal of Microbiology, 2015: 1-8.

Daami-Remadi, M., H. Ben Oun, A. Souissi, M. Mansour, H. Jabnoun-Khiareddine and B. Nasraoui. 2009. Effects of saline irrigation water on verticillium wilt severity and tomato growth. Plant Stress, 3: 40-48.

Davet, P. 1967. Les Maladies des solanées maraichères en Tunisie:(tomate, Piment, Aubergine). Annales de l'INRAT, 4: 24-27.

de Franqueville, H., G. T. Durand, B. Cochard, B. Nouy, F. Breton and J. Dossa. 2011. Integrated approach for management of fusarium disease on the oil palm Proceeding of the third MPOB-IOPRI international seminar on integrated oil palm pest and diseases management. MPOB. Kuala Lumpur. pp. 52-62.

Doohan, F. M., J. Brennan and B. M. Cooke. 2003. Influence of climatic factors on Fusarium species pathogenic to cereals. European Journal of Plant Pathology, 109: 755-68.

FAO. 2013. Bilans alimentaires : production mondiale de l'huile de palme Food and agriculture organization of the United Nations. Division de la statistique, FAOSTAT, série informatique. Rome, Italie. pp. 1486-87.

Flood, J. 2006. A review of fusarium wilt of oil palm caused by Fusarium oxysporum f. sp. elaeidis. Phytopathology, 96: 660-62.

Flowers, T. J. 2004. Improving crop salt tolerance. Journal of Experimental Botany, 55: 307-19.

Ghadiri, H., I. Dordipour, M. Bybordi and M. J. Malakouti. 2006. Potential use of caspian sea water for supplementary irrigation in northern Iran. Agricultural Water Management, 79: 209-24.

Gogbe, D. B. F., J. N. Konan, S. Diabate, E. P. Konan, B. Kone and D. O. Dogbo. 2016. Réaction phénolique de quatre clones de palmier à huile inoculés par Fusarium oxysporum f. sp. elaeidis. International Journal of Biological and Chemical Sciences, 10:
486-96.

Hayashi, H. and N. Murata. 1998. Genetically engineered enhancement of salt tolerance in higher plants. In N Sato Murata (Ed.), Stress Responses of Photosynthetic Organisms: Molecular Mechanisms and Molecular Regulation. Elsevier. Amsterdam. pp. 133-48.

Henry, W. and H. H. Wan. 2012. Effects of salinity on fresh fruit bunch (FFB) production and oil-to-bunch ratio of oil palm (Elaeis guineensis) planted in reclaimed mangrove swamp areas in Sabah. Oil Palm Bulletin, 65: 12-20.

Jacquemard, J.-C. 2012. Le palmier à huile CTA, Presses agronomiques de Gembloux.

Keren, R. 2000. Salinity. In M E Sumner (Ed.), Handbook of soil science. CRC Press. Boca Raton, FL, USA. pp. 3-25.

Kranner, I., R. Beckett and A. Varma. 2002. Protocols in lichenology: culturing, biochemistry, ecophysiology, and use in biomonitoring. In: Richard Beckett and Ajit Varma (eds.), Springer Lab Manuals Springer Nature: Switzerland

Mecteau, M. R., J. Arul and R. J. Tweddell. 2008. Effect of different salts on the development of Fusarium solani var. coeruleum, a causal agent of potato dry rot. Phytoprotection, 89: 1-6.

Ngado, E. G. F., C. E. Eha, G. N. Ntsomboh and T. T. Oben. 2013. Breeding oil palm (Elaeis guineensis jacq.) for Fusarium wilt tolerance: an overview of research programmes and seed production potentialities in Cameroon. International Journal of Agricultural Sciences, 3: 513-20.

Ntsomboh-Ntsefong, G., E.-N. Toussaint, N.-M. A. MadiGaldima, N.-E. G. Frank, K. T. Samuel, M. M. Emmanuel and D. Didier. 2015. Isolation and in vitro characterization of Fusarium oxysporum f. sp. elaeidis, causal agent of oil palm (Elaeis guineensis Jacq.) vascular wilt. Science and Education, 3: 18-26.

Parida, A. K. and A. B. Das. 2005. Salt tolerance and salinity effects on plants: a review. Ecotoxicology and Environmental Safety, 60: 324-49.

Ragazzi, A. and V. Vecchio. 1992. Behaviour of chlamydospore of Fusarium oxysporum f. sp vasinfectum in substrates containing sodium chloride. Phytopathologia Mediterrannea, 31: 8587.

Ramoliya, P. J., H. M. Patel and A. N. Pandey. 2004. Effect of salinization of soil on growth and macro- and 
micro-nutrient accumulation in seedlings of Salvadora persica (Salvadoraceae). Forest Ecology and Management, 202: 181-93.

Regragui, A. 2005. Contribution à l'étude de l'effet de la salinité sur le couple tomate-verticillium: Conséquences physiologiques et impact sur la bioprotection des tomates contre la verticilliose, Université Mohammed V.

Renard, J. L. and A. Ravisé. 1986. La fusariose du palmier à huile. Phytoma: 44-46.

Rossi, V., A. Ravanetti, E. Pattori and S. Giosuè. 2001. Influence of temperature and humidity on the infection of wheat spikes by some some fongi causing Fusarium head blight. Journal of Plant Pathology, 83: 189-98.

Sánchez-Blanco, M. J., T. Ferrández, M. A. Morales, A. Morte and J. J. Alarcón. 2004. Variations in water status, gas exchange, and growth in Rosmarinus officinalis plants infected with Glomus deserticola under drought conditions. Journal of Plant Physiology, 161: 675-82.

Sánchez, F. J., M. a. Manzanares, E. F. de Andres, J. L. Tenorio and L. Ayerbe. 1998. Turgor maintenance, osmotic adjustment and soluble sugar and proline accumulation in 49 pea cultivars in response to water stress. Field Crops Research, 59: 225-35.

Sanogo, S. 2004. Response of chile pepper to Phytophthora capsici in relation to soil salinity. Plant Disease, 88: 205-09.

Tengoua, F. F. and C. Bakoumé. 2008. Pathogenecity of Cameroon strains of Fusarium oxysporum f. sp. elaeidis the causal agent of oil palm vascular wilt. Planter, 84: 233-37.

Triky-Dotan, S., U. Yermiyahu, J. Katan and A. Gamliel. 2005. Development of crown and root rot disease of tomato under irrigation with saline water. Phytopathology, 95: 1438-44.

Xu, X.-M., P. Nicholson, M. Thomsett, D. Simpson, B. Cooke, F. Doohan, J. Brennan, S. Monaghan, A. Moretti and G. Mule. 2008. Relationship between the fungal complex causing Fusarium head blight of wheat and environmental conditions. Phytopathology, 98: 69-78.

Yeo, A. 1998. Predicting the interaction between the effects of salinity and climate change on crop plants. Scientia Horticulturae, 78: 159-74.

Yoshiba, Y., T. Kiyosue, K. Nakashima, K. YamaguchiShinozaki and K. Shinozaki. 1997. Regulation of levels of proline as an osmolyte in plants under water stress. Plant and Cell Physiology, 38: 1095-102.

\section{Supplementary Files:}

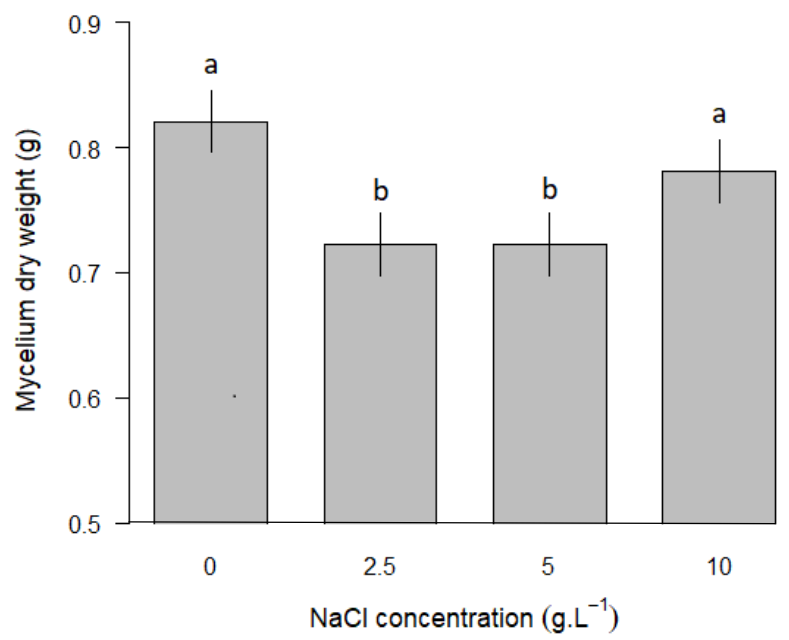

Figure S1. Corrected means of average radial daily growth of Foe for the four $\mathrm{NaCl}$ concentrations. Corrected means with different letters are significantly different for $\alpha=5 \%$. 

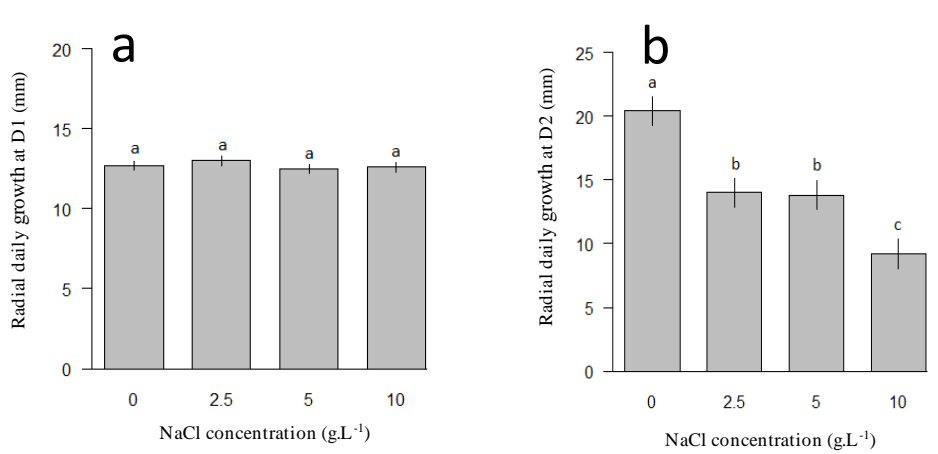

(2)
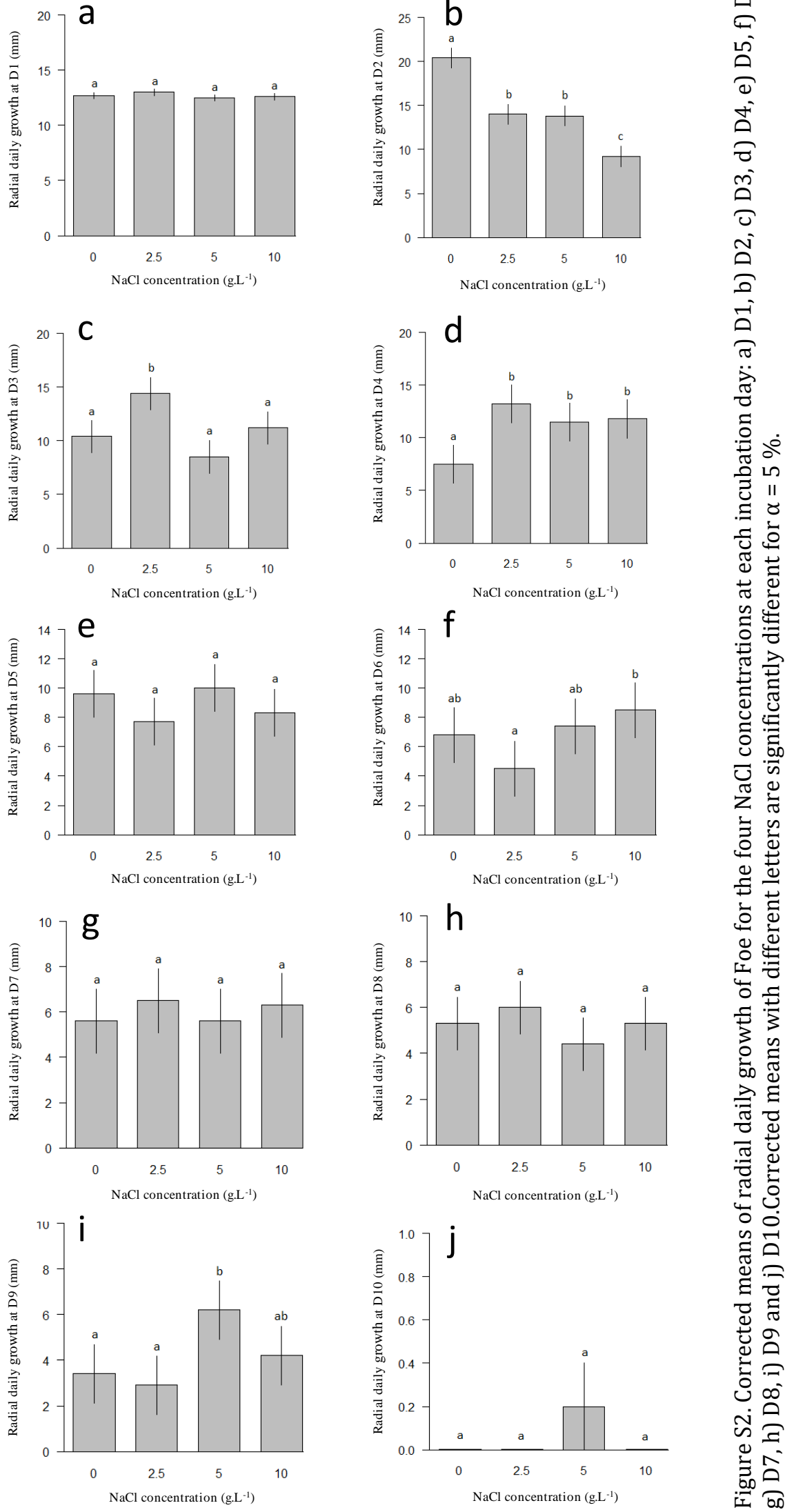

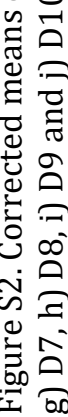




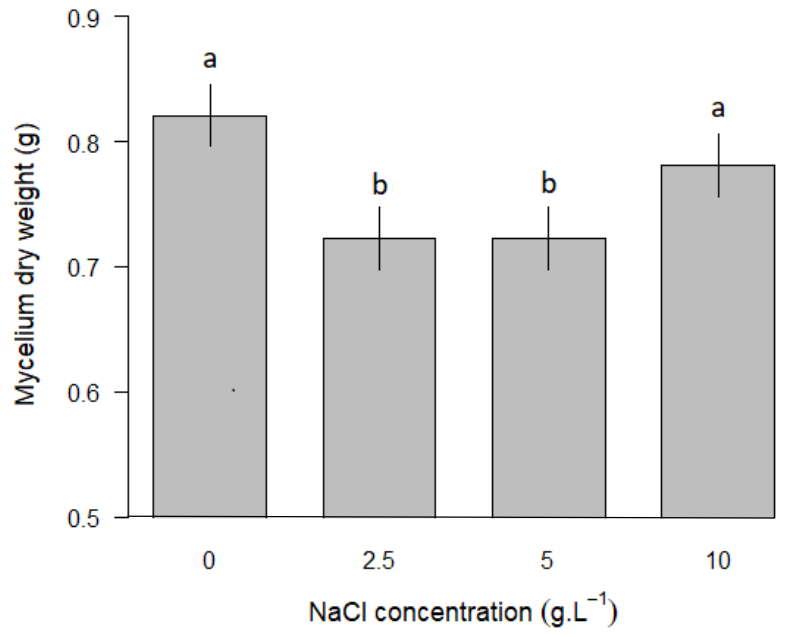

Figure S3. Corrected means of mycelium dry weight of Foe for the four $\mathrm{NaCl}$ concentrations. Corrected means with different letters are significantly different for $\alpha=5 \%$. 

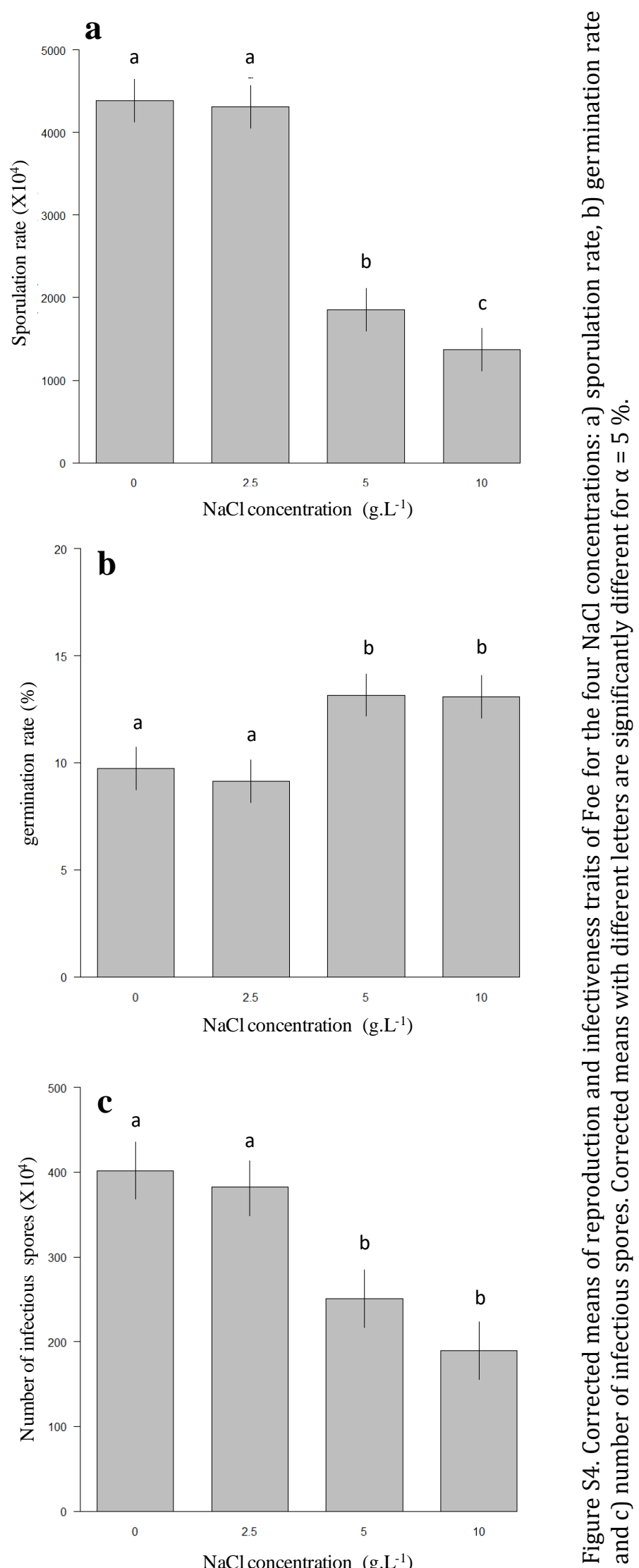
Publisher's note: EScience Press remains neutral with regard to jurisdictional claims in published maps and institutional affiliations.

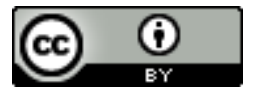

Open Access This article is licensed under a Creative Commons Attribution 4.0 International License, which permits use, sharing, adaptation, distribution and reproduction in any medium or format, as long as you give appropriate credit to the original author(s) and the source, provide a link to the Creative Commons license and indicate if changes were made. The images or other third-party material in this article are included in the article's Creative Commons license, unless indicated otherwise in a credit line to the material. If material is not included in the article's Creative Commons license and your intended use is not permitted by statutory regulation or exceeds the permitted use, you will need to obtain permission directly from the copyright holder. To view a copy of this license, visit http://creativecommons.org/licenses/by/4.0/.

(C) The Author(s) 2019. 